UDK 630*61(497.11 Novi Pazar)

Original scientific paper

\title{
THE STATE OF FORESTS IN THE AREA OF NOVI PAZAR FOREST ADMINISTRATION
}

\author{
Sabahudin HADROVIĆ ${ }^{1}$, Milijana CVEJIĆ ${ }^{l}$
}

\begin{abstract}
This paper presents the state of forests in the area of Novi Pazar forest administration, with the focus on increasing the forest cover area and the volume per area. One of the ways to increase this area is to make it purposeful, i.e., to afforest the land with one single tree species and to put it in the function of biomass production. As can be seen from the paper, the volume per unit of area is small, indicating that the existing stands require adequate measures of forest tending and protection and a strictly defined (projected) allowable cut.
\end{abstract}

Keywords: volume, surface area, afforestation, stands, increment, preservation

\section{СТАЊЕ ШУМА НА ПОДРУЧЈУ ШУМСКЕ УПРАВЕ НОВИ ПАЗАР}

Извод:У раду је приказанано стање шумског фонда на подручју шумске управе Нови Пазар. Поставља се питање како повећати површине под шумом и повећати запремину по површини. Један од начина повећања површине под шумом је да се сво шумско земљиште стави у функцију, односно да се пошуми одговарајућом врстом дрвета и стави у функцију производње биомасе. Из приказаног у раду се види да је запремина по јединици површине мала, што указује на то да постојеће састојине захтевају адекватне мере неге и заштите шума и строго дефинисан (пројектован) сечиви етат који се не сме нарушити.

Кључне речи: запремина, површина, пошумљавање, састојина, прираст, очуваност

\footnotetext{
${ }^{I}$ Dr Sabahudin HADROVIĆl, Mr Milijana CVEJIĆ', Institute of forestry, Belgrade, Serbia Corresponding author: Sabahudin Hadrvić, Kneza Višeslava 3, 11030 Belgrade, Serbia, tel.: +381 113553355 , e-mail: hadrovicsabahudin@gmail.com
} 


\section{INTRODUCTION}

`Novi Pazar` Forest Administration manages state forests and performs expert and technical tasks in the privately-owned forests within the administrative boundaries of the municipality of the same name. Despite the fact that together with private forests, which account for $2 / 3$ of the forests in the area, forests cover over $50 \%$ of the area of Novi Pazar, the state of state-owned and privately-owned forests is unsatisfactory. Special attention should be paid to increasing the area of forest land, which would subsequently increase the volume per unit area through adequate forest tending measures and gradual conversion of stands into high forests (Aleksić et al, 2007). It is not an easy task to increase the forest cover and the attempts made at the state level have yielded only partial results. Compared to the reference year 1979, the Republic of Serbia has increased its forest cover by 5.2\%, which has certainly had a positive impact on the state and quality of the environment. With regard to the population, there is 0.3 ha of forest per capita, which is significantly lower compared to other countries (Russia 11.11 ha per capita, Norway 6.93 ha, Finland 5.91 ha, B\&H 1.38 ha, Croatia 1.38 ha) (Banković et al., 2009).

The data obtained at the state level clearly reflect the state in 'Novi Pazar' Forest Administration, which is a part of SE 'Srbijašume', Belgrade and faces all the problems that other areas of the Republic of Serbia are confronted with. It is, therefore, necessary that each forest administration within the system intensifies its efforts to protect and conserve forests and gradually increases the forest area and wood volume (Hadrović, Stevović, 2017).

\section{MATERIAL AND METHODS}

The data obtained from the Forest Management Plan of `Gornji Ibar` Area and six management units managed by `Novi Pazar` forest administration were used for the purpose of this paper. They cover the areas utilized by SE 'Srbijašume', Belgrade. Data on privately-owned forests were obtained from the Forest Management Programme for privately-owned forests.

\section{RESULTS}

'Novi Pazar' Forest Administration is a user of 16,552.22 ha of forests and forest land and performs expert and technical tasks on 25,724 hectares owned by natural persons. In the area utilized by SE 'Srbijašume', there are 11,761.86 hectares of stocked and 4,790.36 hectares of unstocked land, 4413.32 hectares of which is forest land. The forests and forest land of this Forest Administration are divided into six management units: Crni Vrh-Deževski, Debeljak-Medenovac, Blizanac-Debelica, Ninaja-Koznik, Turjak-Vršine and Vinorog, with an average surface area of 2,758.70 ha. 
Table 1. The area of forests and forest land by management units in `Novi Pazar' Forest Administration

\begin{tabular}{|l|r|r|r|r|r|r|r|}
\hline \multicolumn{1}{|c|}{ MU } & \multicolumn{1}{c|}{$\begin{array}{c}\text { Total } \\
\text { area }\end{array}$} & Forests & \multicolumn{1}{c|}{$\begin{array}{c}\text { Forest } \\
\text { plantations }\end{array}$} & \multicolumn{1}{c|}{$\begin{array}{c}\text { Forest } \\
\text { land }\end{array}$} & $\begin{array}{c}\text { Barren } \\
\text { land }\end{array}$ & Other & $\begin{array}{l}\text { Duration of } \\
\text { the Plan }\end{array}$ \\
\hline $\begin{array}{l}\text { Crni } \\
\text { Vrh/Deževski }\end{array}$ & 2805.74 & 2206.99 & 123.02 & 401.84 & 44.35 & 29.54 & $2005-2014$ \\
\hline $\begin{array}{l}\text { Debeljak- } \\
\text { Medenovac }\end{array}$ & 1639.13 & 1314.16 & 85.71 & 170.01 & 62.01 & 7.24 & $2009-2018$ \\
\hline $\begin{array}{l}\text { Blizanac- } \\
\text { Debelica }\end{array}$ & 2381.43 & 1076.63 & 197.70 & 1081.47 & 5.70 & 19.93 & $2008-2017$ \\
\hline Ninaja-Koznik & 4016.71 & 2558.88 & 141.43 & 1215.40 & 84.65 & 16.35 & $2011-2020$ \\
\hline Turjak-Vrsina & 3391.57 & 2538.68 & 202.03 & 585.21 & 55.78 & 9.87 & $2008-2017$ \\
\hline $\begin{array}{l}\text { Vinorog- } \\
\text { Paunje }\end{array}$ & 2317.64 & 1316.55 & 0.08 & 959.39 & 34.06 & 7.56 & $2008-2017$ \\
\hline Total & 16552.22 & 11011.89 & 749.97 & 4413.32 & 286.55 & 90.49 & \\
\hline
\end{tabular}

Source: Forest Management Plans for forest administrations of `Crni Vrh-Deževski', 'Debeljak-Medenovac', 'Blizanac-Debelica', 'Ninaja-Koznik’, 'Turjak-Vrsina' and 'Vinorog-'Paunje'

As can be seen from Table 1, forests and forest plantations occupy 11,761.86 ha. These are the areas which could provide wood biomass, while the forest land with the area of 4,413.32 ha is set aside for potential afforestation which could subsequently increase the area under forest and foster biomass production. Out of the total area of forest land, $26.60 \%$ is the land suitable for afforestation.

Table 2 shows the areas that are suitable for afforestation. All of these areas should be put to the purpose of biomass production or some other multiple benefits, such as carbon capture and storage (Hadrović, 2015).

Table 2. Potential areas for afforestation

\begin{tabular}{|c|c|r|r|r|}
\hline S.N. & Management unit & Total area in ha & $\begin{array}{c}\text { Area suitable } \\
\text { for afforestation }\end{array}$ & \multicolumn{1}{c|}{ Ratio in \% } \\
\hline 1 & Crni Vrh-Deževski & $2.805,74$ & 401,84 & 14.32 \\
\hline 2 & Debeljak-Medenovac & $1,639.13$ & 170.01 & 10.37 \\
\hline 3 & Blizanac-Debelica & $2,381.43$ & 1081.47 & 45.41 \\
\hline 4 & Ninaja-Koznik & $4,016.71$ & 1215.40 & 30.25 \\
\hline 5 & Turjak-Vrsina & $3,391.57$ & 585.21 & 17.25 \\
\hline 6 & Vinorog Paunje & $2,317.64$ & 959.39 & 41.39 \\
\hline & Total & 16.552 .22 & 4.413 .32 & 26.60 \\
\hline
\end{tabular}

Source: Forest Management Plan of `Gornji-Ibar` Forest Area

\section{DISCUSSION}

The total volume in this forest administration amounts to $1,103,036.5 \mathrm{~m}^{3}$ or $17.5 \%$ of the total volume of the state-owned forest area. The current volume increment is $28,193.3 \mathrm{~m}^{3}$ or $17.4 \%$. The average volume of the stocked surface area is $93.8 \mathrm{~m}^{3} / \mathrm{ha}$ and the current volume increment is $2.4 \mathrm{~m}^{3} / \mathrm{ha}$, or $2.6 \%$ (Hadrović, 2015).

The largest area is covered in coppice forests which account for $17.9 \%$ of the area, followed by mixed coppice forests of sessile oak with $12.9 \%$, even-aged 
high forests of beech with $10.1 \%$, artificially-established stands of spruce with $7.8 \%$, devastated beech forests with $6.1 \%$, mixed coppice forests of Turkey oak with $5.7 \%$, mixed coppice forests of beech with $5.1 \%$ and other stand components that occur on small surface areas (below 5.0\%).

Broadleaves account for $86.9 \%$ of the volume and conifers for $13.1 \%$. Beech is the most common tree species with $57.2 \%$ of volume, followed by sessile oak with $17.7 \%$, Turkey oak with $8.6 \%$, Austrian pine with $6.3 \%$, spruce with $4.6 \%$, hornbeam with $2.1 \%$, while other tree species account for less than $1.0 \%$ of the volume. Small-diameter wood accounts for $69.6 \%$ of the total growing stock, while the share of medium-diameter wood amounts to $26.1 \%$ and large-diameter wood to $4.2 \%$.

This forest administration has 2,423.34 ha (20.6\%) of high forests, with an average volume of $171.8 \mathrm{~m}^{3} / \mathrm{ha}$ and the current volume increment of $4.1 \mathrm{~m}^{3} / \mathrm{ha}$, which makes the percentage of the volume increment $2.4 \%$. Coppice stands occur on $6,593.74$ ha $(56.1 \%)$, with an average volume of $97.8 \mathrm{~m}^{3} / \mathrm{ha}$ and the current volume increment of $2.5 \mathrm{~m}^{3} / \mathrm{ha}$, or $2.6 \%$. Artificially-established stands cover $1,729.98$ ha (14.7\%), with an average volume of $24.3 \mathrm{~m}^{3} / \mathrm{ha}$ and the current volume increment of $1.0 \mathrm{~m}^{3} / \mathrm{ha}$, or $4.0 \%$. Thickets participate with 434.88 ha $(3.7 \%)$ and degraded thickets with 579.92 ha or $4.9 \%$ of the total stocked area of this management unit.

Depending on the level of stand preservation, stands in the investigated area can be divided as follows: 1) well-preserved stands that account for 7,788.44 ha $(66.2 \%)$, with an average volume of $120.0 \mathrm{~m}^{3} / \mathrm{ha}$ and the current volume increment of $3.1 \mathrm{~m}^{3} / \mathrm{ha}$, while the volume increment expressed in the percentage amounts to $2.6 \%$; 2 ) sparsely-closed stands that occur on $1.520,99$ ha $(12.9 \%)$ with an average volume of $76.4 \mathrm{~m}^{3} / \mathrm{ha}$ and the current volume increment of $1.9 \mathrm{~m}^{3} / \mathrm{ha}$, or $2.6 \%$ and 3) devastated stands that are found on $1,437.63$ ha (12.2\%), with an average volume of $36.5 \mathrm{~m}^{3} / \mathrm{ha}$ and the current volume increment of $0.7 \mathrm{~m}^{3} / \mathrm{ha}$, or $1.9 \%$.

\section{CONCLUSIONS}

It seems that the area of 'Novi Pazar' Forest Administration is rich in forests. Unfortunately, this is not completely true, but it is true that over $50 \%$ of its area is covered in forest. As much as $69.6 \%$ of the total growing stock is smalldiameter wood, which indicates that the projected assortment structure is unsatisfactory. This is the reason fire wood accounts for as much as $90 \%$ of the obtained wood assortment.

The average volume of the stocked area is $93.8 \mathrm{~m}^{3} / \mathrm{ha}$, and the current volume increment is $2.4 \mathrm{~m}^{3} / \mathrm{ha}$ or $2.6 \%$, which is far below the average values for Serbia.

Well-preserved high forests account for only $10 \%$ of the area. The share of artificially-established stands of spruce and pine amounts to $14.7 \%$. They require tending measures that entail a lot of work and substantial financial resources in order to preserve them. It is evident that afforestation of barren land has been carried out exclusively with coniferous trees, completely neglecting noble broadleaves and fruit trees. 
There is a significant share of devastated forests that are on good soil and need to be converted into high forests. These are mostly fodder beech forests that were formed some fifty years ago. They should be removed, avoiding the previous practice of amelioration or species replacement with spruce.

Sparsely-closed stands that cover 1,20.99 ha (12.9\%) and devastated stands that are found on $1,437.63$ ha $(12.2 \%)$ should be restocked with noble broadleaves and a sufficient number of forest fruit trees.

There is a large share of unstocked areas suitable for afforestation. Table 2 provides data on the areas suitable for afforestation. This data should be taken with reserve because there are areas that have largely been afforested naturally. The unstocked area has been reduced, but there are still large areas to be afforested in order to put the entire forest land in the function of biomass production and subsequently other multiple forest functions (Hadrović, 2015).

\section{REFERENCES}

Aleksić, P., Stingić, M., Milić, S. (2007): The state of the forests and forest land managed by SE 'Srbijašume', 'Forestry' Journal, vol. 59, no. 3-4, p. 33-54, Belgrade.

Banković, S., Medarević, M., Pantić, D., Petrović, N. (2009): National Forest Inventory of the Republic of Serbia (Growing Stock of the Republic of Serbia). Ministry of Agriculture, Forestry and Water Management of the Republic of Serbia - Forest Administration, p. 1244, Belgrade.

Hadrović, S. (2015): Carbon and Nitrogen Accumulation in Organic Litterfall, Forest Soil and Forest Biomass, Ph.D. thesis, 'Union - Nikola Tesla` University, Faculty of Ecology and Environmental Protection, Belgrade.

Hadrović S., Stevović S. (2017): Biomass from forest waste in the Novi Pazar region as a renewable energy source - V International Scientific Conference Agribusiness MAK 2017Europen road - IPARD-2015-2020., 27- 28 January, Kopaonik-Serbia (171-177).

Forest Management Plan for `Gornji Ibar` forest area

Forest Management Plan for `Blizanac-Debelica` Management Unit

Forest Management Plan for `Vinorog-Paunje` Management Unit

Forest Management Plan for `Debeljak-Medenovac` Management Unit

Forest Management Plan for `Ninaja-Koznik` Management Unit

Forest Management Plan for `Turjak-Vršine` Management Unit

Forest Management Plan for `Crni Vrh-Deževski` Management Unit 


\title{
THE STATE OF FORESTS IN THE AREA OF NOVI PAZAR FOREST ADMINISTRATION
}

\author{
Sabahudin HADROVIĆ, Milijana CVEJIĆ
}

\begin{abstract}
Summary
The research shows that in the area of forest management Novi Pazar, forests and forest land occupy more than $50 \%$ of the area. They are dominated by the forests of mainly red beech and oak (sycamore and zeros), while coniferous tree species (black pine and spruce) are represented in smaller extent between the high and offshore forests is unfavorable, the reason is alarming in private forests. In the last period there is an effort to increase the area under the forest. This is done through afforestation bare. It is a good attempt to produce results in time, in increasing the area and volume of the wood mass.

It is necessary that in the whole area all the surfaces that are now being treated as bare are afforested with an adequate tree species. So far, the practice has been that the afforestation be done exclusively with the seedlings of the conifers. It is necessary to conduct and afforestation also with the species of the trees with mandatory insertion of a certain number of seedlings forest fruit trees.

Privately owned in the area of Novi Pazar there are significant areas that are suitable for afforestation. The problem is that these surfaces are small and divided and that there is a lack of workforce.
\end{abstract}

\section{СТАЊЕ ШУМА НА ПОДРУЧЈУ ШУМСКЕ УПРАВЕ НОВИ ПАЗАР}

\author{
Сабахудин ХАДРОВИЋ, Милијана ЦВЕЈИЋ
}

\section{Резиме}

Из приложеног се види да на подручју шумске управе Нови Пазар, шуме и шумско земљиште заузимају више од 50\% простора.Доминирају шуме лишћара углавном букве и храста (китњака и цера), док су четинарске врсте дрвећа (црни бор и смрча) заступљени у мањем обиму.Однос између високих и изданачких шума је неповољан, погото је то стаље алармантно у приватним шумама .У последњем периоду запажа се напор на повећању површине под шумом.То се ради кроз пошумљавање голети. То је добар покушај који ће временом дати резултате, у повечању површине и запремине дрвне масе.

Неопходно је да на целом подручју све површине које се сада воде као голети пошумити адекватниом врстом дрвећа.До сада је пракса била да се пошумљављављње врши исккључиво садницама четинара.То је потребно напустити и пошумљавање вршити и са лишћарским врстама дрвећа уз обавезно убацивање одређеног броја садница шумских воћкарица.

У приватном власништву на подручју Новог Пазара постоје знатне површине које су погодне за пошумљавање.Проблем је што су те површине уситњене и што недостаје радне снаге која би тај посао обавила. 